\title{
Construction and validation of an ADHD screening tool for preschool children: A study with Spanish population
}

\section{Construcción y validación de una escala de cribado de TDAH para niños preescolares: Un estudio con población española}

\author{
Manuel Rodríguez-Becerra ${ }^{1}$, Luz María Fernández-Mateos ${ }^{1}$, Cristina Jenaro * 2 \\ 1 - Facultad de Educación, Universidad Pontificia de Salamanca, España. \\ 2 - INICO/Facultad de Psicología. Salamanca, España.
}

Introduction

Method

Results

Discussion

References

Recibido: 26/01/2019 Revisado: 29/03/2019 Aceptado: 04/04/2019

\begin{abstract}
Most cases of ADHD occur in children under five, and this situation calls for screening tools with high sensitivity and specificity for early age. This study presents the ADHD-3P, a new screening tool developed with Spanish population for preschool children. From an initial pool of 151 items, face validity analyses, followed by item analyses and analysis of the scale, were carried out. A 27 -item scale $(\alpha=.95)$ composed of three factors: hyperactivity $(\alpha=.92)$, inattention $(\alpha=.92)$, and other symptoms $(\alpha=.81)$ resulted from the analyses. Discriminant power was high $(89.7 \%$ for ADHD, and $88.3 \%$ for non-ADHD). Diagnostic performance was evaluated through Receiver-Operating Characteristic curves, and excellent sensitivity $(92.86 \%)$ and specificity $(89.86 \%)$ were obtained. In sum, the ADHD-3P is a promising tool to be used by parents, teachers, and pediatricians.
\end{abstract}

Keywords: attention-deficit/hyperactivity disorder, screening, preschoolers, psychometrics, measure development

\section{Resumen}

La mayoría de los casos de TDAH suceden en niños menores de cinco años, y esta situación requiere de herramientas de cribado con elevada sensibilidad y especificidad para edades tempranas. Se presenta la ADHD-3P, una nueva herramienta de cribado desarrollada con población española para niños de preescolar. A partir de 151 ítems, se realizaron análisis de la validez aparente, análisis de los ítems y de la escala. Estos resultaron en una escala de 27 ítems $(\alpha=.95)$ compuesta por tres factores: hiperactividad $(\alpha=.92)$, inatención $(\alpha=.92)$ y otros sintomas $(\alpha=.81)$. El poder discriminativo de la escala fue elevado (89.7\% para niños con TDAH y $88.3 \%$ para niños sin TDAH). La capacidad diagnóstica fue evaluada mediante curvas ROC y mostró una excelente sensibilidad $(92.86 \%)$ y especificidad (89.86\%). En suma, la ADHD$3 \mathrm{P}$ es una herramienta prometedora para ser utilizada por padres, profesores y pediatras.

Palabras clave: $T D A H$, cribado, preescolar, propiedades psicométricas, desarrollo de escala

\footnotetext{
*Correspondence to: Cristina Jenaro. INICO/Facultad de Psicología. Universidad de Salamanca. Avda. de la Merced, 109-131. 37005-Salamanca. Tel. (+34) 923294685. Fax. (+34) 923294695. E-mail: crisje@usal.es

How to cite: Rodríguez-Becerra, M., Fernández-Mateos, L. M., \& Jenaro, C. (2019). Construction and validation of an ADHD screening tool for preschool children: A study with Spanish population. Revista Evaluar, 19(2), 30-42. Recuperado de https://revistas.unc.edu.ar/index.php/revaluar
} 


\section{Introduction}

Attention Deficit Hyperactivity Disorder (ADHD; American Psychiatric Association, 2013), or Attention and Activity Disorder (World Health Organization, 2010) is one of the most prevalent neurodevelopmental disorders in the child population. Both the DSM (Diagnostic and Statistical Manual of Mental Disorders; American Psychiatric Association, 2013) and the ICD (International Classification of Diseases; World Health Organization, 2010, 2018) manuals designate attention deficit, hyperactivity and impulsivity as core symptoms. An overall prevalence of between $8 \%$ and $12 \%$ is estimated (American Psychiatric Association, 2013; World Health Organization, 2010, 2018) and there is a general consensus regarding the underestimation of the ADHD (Rowland et al., 2001). Regarding clinical presentations, there is some agreement that inattentiveness is more common, and that for every girl diagnosed with ADHD there are three boys (Willkut, 2012).

The impact of ADHD on children and their families is widely known, hence the importance of early detection (Hurtig, Taanila, Moilanen, Nordström, \& Ebeling, 2012; Kooij et al., 2010; Sikirica et al., 2015; Wehmeier, Schacht, \& Barkley, 2010). But detection is not easy for several reasons: (1) the diversity of clinical presentations (Costa-Dias et al., 2013; Potter, Dunbar, Mazzu1la, Hosford, \& Newhouse, 2014); (2) the onset of the disorder coincides with some age-related behaviors (Reyes-Sandoval \& Acuña, 2012; Vaquerizo-Madrid, 2005); (3) the symptoms overlap with other disorders, such as Oppositional Defiant Disorder or Disruptive Mood Dysregulation Disorder (Mulraney et al., 2016) and (4) some of the behavioral disorders overlap with other emotional disorders, such as anxiety-related disorders (Overgaard, Aase, Torgersen, \& Zeiner, 2016). In sum, ADHD, rather than being a homogeneous entity, is a group of conditions with potentially different etiological and risk factors and with different outcomes (Costa-Dias et al., 2013; Spencer, Biederman, \& Mick, 2007).

This situation calls for screening tools with high sensitivity and specificity for early age, as most cases of ADHD occur in children under five (Vaquerizo-Madrid, 2005). Existing scales, such as the ADHD Symptom Checklist-4 (ADHD-SC4), have shown moderate sensitivity (Sprafkin, Gadow, \& Nolan, 2001). The Attention Problem Scale of the Child Behavior Checklist (CBCL-APS) has shown moderate diagnostic performance (Lampert, Polanczyk, Tramontina, Mardini, \& Rohde, 2004), as has the Pediatric Attention Disorders Diagnostic Screener (PADDS; Newman \& Reddy, 2017) and the Persian version of the Conners' Adult Attention-Deficit/Hyperactivity Disorder (ADHD) Screening Scale (Davari-Ashtiani, Jazayeri, Arabgol, Razjouyan, \& Khademi, 2014). Moderate levels of discriminant power have been obtained with the Face Stimulus Assessment (FSA; Betts, 2003; Kim, Kim, $\&$ Seo, 2014) and other novel tools such as the AAPS (Brownlie, Lazare, \& Beitchman, 2012). Additionally, moderate agreement levels have been found between diagnoses obtained with different screening tools (Posserud et al., 2014).

While several scales for assessing ADHD in preschool populations through proxies or key informants are currently available, there are few studies that prove the diagnostic capability of the screening tools in early childhood. Also, existing studies show a relatively low diagnostic capability (Holmberg, Sundelin, \& Hjern, 2013; Lampert et al., 2004), which results in false positives (Sayal, Letch, \& El Abd, 2008).

Additional limitations are related to poor agreement in the assessment of symptoms (Levin-Decanini, Connolly, Simpson, Suarez, \& 
Jacob, 2013; Re \& Cornoldi, 2009) and a lack of consensus between parents' and teachers' assessments (Deb, Dhaliwal, \& Roy, 2008; Efstratopoulou, Simons, \& Janssen, 2013; Power, Costigan, Leff, Eiraldi, \& Landau, 2001; Raiker et al., 2017; Re \& Cornoldi, 2009; Wolraich et al., 2004). The choice of screening strategy significantly affects how teachers report on ADHD symptoms at school. The halo effect of externalizing behaviors impacts on the correct identification of true cases of ADHD in the school setting (Kieling et al., 2014).

Another limitation of existing studies relates to the need to take cultural factors into account, as these even affect the perception of the severity of ADHD symptoms (CEAL-TDAH, 2009; Hillemeier, Foster, Heinrichs, \& Heier, 2007; Norvilitis, Ingersoll, Zhang, \& Jia, 2008). Hence the importance of instruments adapted to culture (Cornelio-Nieto, Borbolla-Sala, \& García-Valdovinos, 2010). In sum, policies, research, and applied decisions depend on measurement instruments and the quality of decisions depends on the quality of the instruments (Danner et al., 2016; Ziegler, 2014).

Thus, in order to help overcome current shortcomings, this study developed the ADHD3P scale. The name refers to the three informants who best know the child: Parents, Professors (teachers) and Pediatricians. This paper presents the process used to investigate the psychometric properties of the scale. First, we examined the adequacy of content; second, we examined the face validity of the scale. Next, we assessed its reliability and validity, which is understood as the degree to which all the accumulated evidence supports the intended interpretation of test scores for the intended purposes (AERA, APA, \& NCME, 1999 , as cited in Goodwin \& Leech, 2003). It includes evidence from experts and judges' reviews on the test content, evidence on internal structure by means of exploratory factor analysis and evidence on relations to other variables, specifically construct validity, and convergent and discriminant validity (Goodwin \& Leech, 2003). Lastly, we examined the sensitivity and specificity of the scale for early identification of the first clinical manifestations compatible with ADHD and the cutoffs that distinguish between the clinical and nonclinical populations.

\section{Method \\ Participants}

This study required the participation of four different groups for the next steps (see Table 1). The first step required expert raters for face validity. A total of 16 experts, consisting of parents, professors, and pediatricians were consulted. The second step included a large sample of parents $(\mathrm{N}=644)$ of children with $(\mathrm{n}=281)$ and without ADHD ( $\mathrm{n}=363$ ), to perform item analyses as well as Cronbach's alpha reliability tests and exploratory factor analysis. The third step utilized a sample of 79 informants who filled out the measure twice, for test-retest analyses. The fourth step utilized a sample of 54 parents of children with $(n=35)$ and without ADHD $(n=19)$ to determine the diagnostic accuracy of the developed measure. In all cases, confidentiality and voluntariness were guaranteed and the provisions of the participating agencies ethics' committees have been followed.

\section{Measures}

In addition to the ADHD-3P scale, whose development and characteristics are detailed in this research, the SNAP-IV Teacher and Parent Rating Scale (18 items; Swanson et al., 2001) was 
used for the analysis of convergent validity and comparison of the diagnostic performance of both scales. This test is a hetero-report, completed by parents and teachers of children between 3 and 17 years to assess the presence and severity of behaviors consistent with ADHD. The 18 items (nine questions in the attention subscale and nine for hyperactivity / impulsivity) are scored on a Likert scale from 0 (none) to 3 (very much) points. Several studies support the sensitivity and specificity of the SNAP-IV (Alda \& Serrano-Troncoso, 2013; Berrocal et al., 2011; Bussing et al., 2008) and so, the demonstrated quality of that measure served as the basis for its use in this study.

\section{Procedure}

The instrument was developed using the procedure summarized in Table 1. The preliminary step consisted in the development of an initial set of 151 items commonly used for assessing ADHD in children. The authors of the current study were responsible for their initial selection from existing measures in different languages. Clinical criteria and clinical experience with the targeted population were also the basis for the development of some of the items. The number of initial items was considered reasonable given the expected dimensions and the final configuration of the screening tool (Netemeyer, Bearden, \& Sharma, 2003).

\section{Results}

The ratings obtained by the 16 judges $(\mathrm{n}=$ 8 teachers, $n=5$ parents, and $n=3$ pediatricians) led to the retention of $45(29.8 \%)$ of the original 151 items, which were found relevant, intense and clear enough for preschool children. Relevance and intensity were defined as an average score higher than 2.5 in a 1 to 4 scale. The clarity of the items was tested with the most common reliability coefficients for multiple coders assessing nominal data: the average pairwise percent agreement, Fleiss' kappa, average pairwise Co-

\section{Table 1}

Summary of the procedure (steps and tasks) followed in the development and validation of the ADHD-3P scale.

\section{Steps and Tasks}

Step 1: (Face validity) Consultation of 16 expert judges and ratings on:

1. Category

2. Intensity

3. Relevance

Step 2: Construction and application of a (45-item) preliminary version of the scale

1. Item Analyses (discriminative power, internal consistency)

Step 3: Application and analysis of the scale (27-item)

1. Factor analysis

2. Internal consistency

3. Agreement between raters

4. Stability (test-retest)

5. Construct validity

6. Convergent validity: correlations with the SNAP IV

7. Discriminant validity

8. Diagnostic capability (obtaining ROC curves) and testing with ADHD preschool children 
hen's kappa, and the Krippendorff's alpha (Freelon, 2010). Next, the items analyses required to calculate the discriminative power of the items by means of $t$-test for independent groups (i.e. with or without ADHD). All items reached a confidence level of 1 per $1000(p<.001)$. Then, we calculated the internal consistency coefficients of the items: Items with low corrected homogeneity (defined as values below .20) were excluded from further analysis resulting in 27 items.

Step 3, analysis of the scale (see Table 1), involved eight tasks. First, exploratory factor analysis was performed with the remaining 27 items. Principal component analysis with oblimin rotation was performed, as a correlation between the extracted factors was expected, provided that the samples were big enough (KMO-test greater than .5; Field, 2000; Tabachnick \& Fidell, 2007). Analyses led to the identification of three factors (loadings between .35 and .92). Thus, the final scale comprised of 27 items grouped into three factors. Table 2 shows the eigenvalues and percentages of explained variance. Analysis of subscales internal consistency was then performed and the findings indicated high reliability for hyperactivity $(\alpha=.92)$, inattention $(\alpha=.92)$ and other symptoms -impulsivity, irritability- $(\alpha=$ $.81)$, as well as for the scale total scores $(\alpha=.95)$.

Table 2

Eigenvalues and explained variance (three-factor solution with varimax rotation).

\begin{tabular}{llcc}
\hline Component & Total & \% variance & \% accumulated \\
\hline 1 Hyperactivity $(\mathrm{n}=12)$ & 10.38 & 38.43 & 38.43 \\
2 Inattention $(\mathrm{n}=9)$ & 3.74 & 13.85 & 52.28 \\
3 Other symptoms $(\mathrm{n}=6)$ & 1.71 & 6.32 & 58.60 \\
\hline
\end{tabular}

Note. Method of extraction: principal components analysis. Oblimin rotation.

Task 3 (see Table 1) was to assess the agreement between raters. The analyses resulted in significant medium-high correlations between the ratings of both parents of the children with ADHD ( $r=.52$ for inattention, $r=.80$ for hyperactivity, and $r=.80$ for other symptoms). The fourth task, determining the stability of the assessments, was calculated using the test-retest correlation between ratings of the informants. Values were higher than .98 for the different dimensions, which guarantees high stability.

The fifth task (Table 1), construct validity of the scale, required calculating correlations between the dimensions of the scale and age at diagnosis. As expected, the correlation between hyperactivity and age at diagnosis was significant and negative $(r=-.20 ; \mathrm{N}=277 ; p=.001)$. The association was also significant with inattention $(r$
$=-.15 ; \mathrm{N}=277 ; p=.012)$, and with other symptoms $(r=-.21 ; \mathrm{N}=277 ; p<.001)$.

The sixth task required determining the convergent validity of the ADHD-3P with the SNAP IV scale through the correlations between scores on the factors and total scale. Correlations were high for hyperactivity $(r=.80 ; p<.01)$, inattention $(r=.83 ; p<.01)$ and the total scale $(r=.83$; $p<.01)$. The size of the correlations further suggests that while similar content is being assessed, they are not identical, thus the scale under construction adds relevant and new content.

The seventh task (Table 1) was the analysis of the discriminant validity, taking the dimensions of the scale as potentially predictive variables and group membership (i.e. with or without ADHD) as a predicted variable. This led to the obtainment of a discriminant function with an eigenvalue $=1.561$ and canonical correlation $=.78$, 
which accounts for $100 \%$ of the variance (Wilks' $=.39 ; p=.0001)$. Intragroup correlations of each variable with the canonical function were: .95 (inattention), .77 (hyperactivity) and .64 (other symptoms). In total, the function correctly classified for $88.5 \%$ of cases and showed high ability to classify participants with ADHD (i.e. sensitivity; $89.7 \%$ of cases correctly classified, CI: $85.52 \%$ to $92.98 \%$ ), and those without ADHD (i.e. specificity; $88.3 \%$ of cases classified correctly, $95 \% \mathrm{CI}=$ $84.56 \%$ to $91.46 \%$ ).

The eighth task was the comparison of the diagnostic performance of the ADHD-3P against the SNAP-IV, using a sample of 54 cases of which 35 were clinical (i.e. with ADHD) and 19 were non-clinical (i.e. without ADHD). The ADHD$3 \mathrm{P}$ values of the areas under the curve (AUC) revealed the existence of great scale capacity to discriminate between clinical and non-clinical in hyperactivity and inattention (Table 3). Confidence intervals were equally satisfactory for the dimensions of hyperactivity and inattention, and slightly lower for other symptoms. The data were higher than those obtained with the SNAP which only include the two main dimensions of the disorder.
After obtaining the cutoff scores for each of the dimensions that maximize the sensitivity and specificity, we proceeded to test the diagnostic performance of the scale with preschool children ( $\mathrm{n}=69$ nonclinical, and $\mathrm{n}=28$ clinical cases), through Receiver-Operating Characteristic (ROC) curves. Regarding hyperactivity, a cutoff score of 15.10 correctly identified the 26 clinical cases and 53 nonclinical cases. On the other hand, 16 false positives and 2 false negatives were identified. The sensitivity was $92.86 \%$ and the specificity was $76.81 \%$. As for inattention, a cutoff score of 13 correctly identified 24 clinical cases and 65 nonclinical cases. It also identified 4 false positives and 4 false negatives. The sensitivity was $85.71 \%$ and the specificity was $94.20 \%$. Regarding the other symptoms scale, a cutoff score of 7.50 correctly identified 27 clinical cases and 60 nonclinical cases. It also identified 9 false positives and 1 false negative. The sensitivity was $96.43 \%$ and specificity was $86.96 \%$. Finally, considering the ADHD-3P scale overall, a cutoff score of 37.50 correctly identified 26 clinical and 62 nonclinical cases. It also identified 7 false positives and 2 false negatives. The sensitivity was $92.86 \%$ (95\% CI $=76.50 \%$ to $99.12 \%)$ and speci-

Table 3

Area Under the Curve (AUC) of the variables Hyperactivity, Inattention and Other symptoms.

\begin{tabular}{|c|c|c|c|c|c|}
\hline \multirow[b]{2}{*}{ Variables } & \multirow[b]{2}{*}{$\mathbf{A U C}$} & \multirow[b]{2}{*}{ SE } & \multirow[b]{2}{*}{$p$} & \multicolumn{2}{|c|}{$\begin{array}{l}95 \% \text { asymptotic } \\
\text { Confidence limits }\end{array}$} \\
\hline & & & & Lower Limit & Upper Limit \\
\hline \multicolumn{6}{|l|}{ ADHD-3P } \\
\hline Hyperactivity & .98 & .01 & $<.001$ & .96 & 1.01 \\
\hline Inattention & .98 & .02 & $<.001$ & .95 & 1.02 \\
\hline Other symptoms & .86 & .06 & $<.001$ & .75 & 0.97 \\
\hline Total & .97 & .03 & $<.001$ & .93 & 1.02 \\
\hline \multicolumn{6}{|l|}{ SNAP } \\
\hline Hyperactivity & .97 & .02 & $<.001$ & .93 & 1.01 \\
\hline Inattention & .97 & .03 & $<.001$ & .92 & 1.03 \\
\hline Total & .99 & .01 & $<.001$ & .97 & 1.01 \\
\hline
\end{tabular}


ficity was $89.86 \%(95 \% \mathrm{CI}=80.21 \%$ to $95.82 \%)$. The positive likelihood ratio was $9.15(95 \% \mathrm{CI}=$ 4.50 to 18.61$)$ and negative likelihood ratio was $.08(95 \% \mathrm{CI}=.02$ to .31$)$. All results were fully satisfactory.

\section{Discussion}

In this research, we have presented the process utilized to build and validate a brief scale for screening children in early childhood with possible ADHD. The developed scale (see Appendix 1 and 2 for English and Spanish versions, respectively) has shown very high sensitivity for the ADHD diagnosis in Spanish preschool children. This sensitivity is particularly high for the diagnosis of hyperactive symptoms as well as other symptoms. It also provides better results than similar studies with other screening tools (Abdekhodaie, Tabatabaei, \& Gholizadeh, 2012; Alda \& Serrano-Troncoso, 2013; Holmberg et al., 2013). Consequently, this measure contributes to the improvement of the early detection of possible clinical cases of ADHD at early ages, which is always challenging from a clinical point of view. An additional noteworthy fact is that the measure was developed by asking three different groups of informants: parents, teachers, and pediatricians. Each group contributed their visions of the disorder under consideration and their different experiences with it as well as the context (clinical, educational, family) when they need to face it for different purposes (diagnosis, treatment, support, etc.). These differences in purposes and roles offered a broader and more comprehensive view of the disorder and increased the content validity of the developed measure at the same time.

The high reliability obtained, understood as internal consistency, measurement stability and concordance between evaluators, supports great- er measure accuracy than shown in other studies (Erhart, Döpfner, \& Ravens-Sieberer, 2008; Kim et al., 2014). The analysis of content validity (by way of judges), construct validity (through factor analysis), convergent validity (with SNAP) and discrimination (using discriminant analysis and ROC curves) supports confidence in the adequacy of the scale for assessing relevant symptoms in Spanish children with ADHD, and improves on the results of other similar studies with other measures (Bussing et al., 2008; Sprafkin et al., 2001). The diagnostic performance of the ADHD-3P was also higher than that obtained with the SNAP, which only includes the two main dimensions of the disorder. The domain other symptoms includes items on impulsivity, which is acquiring increasing relevance in current factorial models on ADHD (Dumenci, McConaughy, \& Achenbach, 2004).

However, this study is only a first step in the development and consolidation of screening tools for ADHD, and caution against using the ADHD-3P as the only tool for diagnostic purposes is advised. Currently, the predictive ability of the instrument is unknown. This will require the incorporation of children at risk without a diagnosis and subsequent evaluation of sensitivity and specificity. The continued use and dissemination of the ADHD-3P in Spanish and English speaking countries will allow us to answer this and other questions. The inclusion of the questionnaire in the appendix aims to serve as an incentive for use and dissemination in subsequent research efforts.

Yet, despite what we believe is a clear contribution in the field in question, we would like to put an emphasis on the importance of going beyond assessments and not focusing solely on the child. Effective interventions (Mikami et al., 2013) should include not only supports for the child but also for their parents and teachers. Hence the importance of targeting the "three Ps": 
parents, professors, and pediatricians involved in the process of assessment and intervention.

\section{References}

Abdekhodaie, Z., Tabatabaei, S. M., \& Gholizadeh, M. (2012). The investigation of ADHD prevalence in kindergarten children in northeast Iran and a determination of the criterion validity of Conners' Questionnaire via clinical interview. Research in Developmental Disabilities, 33(2), 357-361. doi: 10.1016/j. ridd.2011.10.006

Alda, J. A., \& Serrano-Troncoso, E. (2013). Trastorno por déficit de atención con hiperactividad: Concordancia entre la impresión clínica y el cuestionario de cribado SNAP-IV (Estudio CONCOR). Actas Españolas de Psiquiatría, 41(2), 76-83. Retrieved from https:// www.actaspsiquiatria.es

American Psychiatric Association. (2013). Diagnostic and statistical manual of mental disorders. DSM-5 ( $5^{\text {th }}$ ed.). Washington, DC: American Psychiatric Association. doi: 10.1176/appi.books.9780890425596

Berrocal, M., Peskin, V., Weiss, N., Schuler, J., Monge, S., McGough, J. J., ... Mathews, C. A. (2011). Prevalencia y tamizaje del trastorno por déficit de atención con hiperactividad en Costa Rica. Vertex, Revista de Psiquiatría, 22(99), 337-342. Retrieved from http:// www.polemos.com.ar/vertex.php

Betts, D. J. (2003). Developing a projective drawing test: Experiences with the Face Stimulus Assessment (FSA). Art Therapy: Journal of the American Art Therapy Association, 20(2), 77-82. doi: 10.1080/07421656.2003.10129393

Brownlie, E., Lazare, K., \& Beitchman, J. (2012). Validating a self-report screen for ADHD in early adulthood using childhood parent and teacher ratings. Journal of Attention Disorders, 16(6), 467-477. doi: 10.1177/1087054711398902

Bussing, R., Fernandez, M., Harwood, M., Wei Hou, Gar- van, C. W., Eyberg, S. M., \& Swanson, J. M. (2008). Parent and teacher SNAP-IV ratings of attention deficit hyperactivity disorder symptoms: Psychometric properties and normative ratings from a school district sample. Assessment, 15(3), 317-328. doi: 10.1177/1073191107313888

Comité Internacional para el Desarrollo y Estudio del Cuestionario para Escolares y Adolescentes Latinoamericanos con Trastorno por Déficit de Atención con Hiperactividad (CEAL-TDAH). (2009). Cuestionario para Escolares y Adolescentes Latinoamericanos con Trastorno por Déficit de Atención con Hiperactividad (CEAL-TDAH). Construcción, descripción del instrumento y datos sociodemográficos y clínicos de la muestra. Salud Mental, 32(Supl. 1), 55-62. Retrieved from http://revistasaludmental.mx

Cornelio-Nieto, J. O., Borbolla-Sala, M. E., \& García-Valdovinos, S. (2010). Population-based diagnostic study to compare the DSM-IV and the Questionnaire for screening Latin American schoolchildren and adolescents for attention deficit hyperactivity disorder. Revista de Neurología, 50(3), 119-123. doi: 10.33588/rn.50S03.2010012

Costa-Dias, T. G., Kieling, C., Graeff-Martins, A. S., Moriyama, T. S., Rohde, L. A., \& Polanczyk, G. V. (2013). Developments and challenges in the diagnosis and treatment of ADHD. Revista Brasileira de Psiquiatria, 35(1), 40-50. doi: 10.1590/1516-44462013-S103

Danner, D., Blasius, J., Breyer, B., Eifler, S., Menold, N., Paulhus, D. L. , ... Ziegler, M. (2016). Current challenges, new developments, and future directions in scale construction. European Journal of Psychological Assessment, 32(3), 175-180. doi: 10.1027/10155759/a000375

Davari-Ashtiani, R., Jazayeri, F., Arabgol, F., Razjouyan, K., \& Khademi, M. (2014). Psychometric properties of Persian version of Conners' Adult Attention Deficit/Hyperactivity Disorder Rating Scale (screening form-self reporting). Iranian Journal of Psychiatry and Clinical Psychology, 20(3), 243-251. 
Deb, S., Dhaliwal, A. J., \& Roy, M. (2008). The usefulness of Conners' Rating Scales-Revised in screening for attention deficit hyperactivity disorder in children with intellectual disabilities and borderline intelligence. Journal of Intellectual Disability Research, 52(11), 950-965. doi: 10.1111/j.1365-2788.2007.01035.x

Dumenci, L., McConaughy, S. H., \& Achenbach, T. M. (2004). A hierarchical three-factor model of inattention hyperactivity-impulsivity derived from the attention problems syndrome of the teacher's report form. School Psychology Review, 33(2), 287-301. Retrieved from https://www.nasponline.org/

Efstratopoulou, M., Simons, J., \& Janssen, R. (2013). Concordance among physical educators', teachers', and parents' perceptions of attention problems in children. Journal of Attention Disorders, 17(5), 437-443. doi: 10.1177/1087054711431698

Erhart, M., Döpfner, M., \& Ravens-Sieberer, U. (2008). Psychometric properties of two ADHD questionnaires: Comparing the Conners' scale and the FBBHKS in the general population of German children and adolescents - Results of the BELLA study. European Child \& Adolescent Psychiatry, 17(1), 106-115. doi: 10.1007/s00787-008-1012-1

Field, A. P. (2000). Discovering statistics using SPSS for Windows. London, England: Sage.

Freelon, D. G. (2010). ReCal: Intercoder reliability calculation as a web service. International Journal of Internet Science, 5(1), 20-33. Retrieved from http:// www.ijis.net

Goodwin, L. D., \& Leech, N. L. (2003). The meaning of validity in the new standards for educational and psychological testing: Implications for measurement courses. Measurement and Evaluation in Counseling and Development, 36(3), 181-191. doi: 10.1080/07481756.2003.11909741

Hillemeier, M. M., Foster, E. M., Heinrichs, B., \& Heier, B. (2007). Racial differences in parental reports of attention-deficit/hyperactivity disorder behaviors. Journal of Developmental and Behavioral Pediatrics, 28(5), 353-361. doi: 10.1097/DBP.0b013e31811ff8b8
Holmberg, K., Sundelin, C., \& Hjern, A. (2013). Screening for attention-deficit/ hyperactivity disorder (ADHD): Can high-risk children be identified in first grade? Child: Care, Health and Development, 39(2), 268276. doi: 10.1111/j.1365-2214.2012.01382.x

Hurtig, T., Taanila, A., Moilanen, I., Nordström, T., \& Ebeling, H. (2012). Suicidal and self-harm behaviour associated with adolescent attention deficit hyperactivity disorder-A study in the Northern Finland birth cohort 1986. Nordic Journal of Psychiatry, 66(5), 320-28. doi: 10.3109/08039488.2011.644806

Kieling, R. R., Kieling, C., Aguiar, A. P., Costa, A. C., Dorneles, B. V., \& Rohde, L. A. (2014). Searching for the best approach to assess teachers' perception of inattention and hyperactivity problems at school. $E u$ ropean Child \& Adolescent Psychiatry, 23(6), 451459. doi: 10.1007/s00787-013-0466-y

Kim, J., Kim, G., \& Seo, S. (2014). Validation of the FSA as screening tool for children with ADHD. The Arts in Psychotherapy, 41(4), 413-423. doi: 10.1016/j. aip.2014.04.006

Kooij, S. J. J., Bejerot, S., Blackwell, A., Caci, H., Casas-Brugué, M., Carpentier, P. J., ... Asherson, P. (2010). European consensus statement on diagnosis and treatment of adult ADHD: The European Network Adult ADHD. BMC Psychiatry, 10, 1-24. doi: 10.1186/1471-244x-10-67

Lampert, T. L., Polanczyk, G., Tramontina, S., Mardini, V., \& Rohde, L. A. (2004). Diagnostic performance of the CBCL-Attention Problem Scale as a screening measure in a sample of Brazilian children with ADHD. Journal of Attention Disorders, 8(2), 63-71. doi: 10.1177/108705470400800204

Levin-Decanini, T., Connolly, S. D., Simpson, D., Suarez, L., \& Jacob, S. (2013). Comparison of behavioral profiles for anxiety-related comorbidities including ADHD and selective mutism in children. Depression and Anxiety, 30(9), 857-864. doi: 10.1002/da.22094

Mikami, A. Y., Griggs, M. S., Lerner, M. D., Emeh, C. C., Reuland, M. M., Jack, A., \& Anthony, M. R. (2013). A randomized trial of a classroom intervention to 
increase peers' social inclusion of children with attention-deficit/hyperactivity disorder. Journal of Consulting and Clinical Psychology, 81(1), 100-112. doi: $10.1037 / \mathrm{a} 0029654$

Mulraney, M., Schilpzand, E. J., Hazell, P., Nicholson, J. M., Anderson, V., Efron, D. E., \& Silk, T. J. (2016). Comorbidity and correlates of disruptive mood dysregulation disorder in 6-8-year-old children with ADHD. European Child \& Adolescent Psychiatry, 25(3), 321-330. doi: 10.1007/s00787-015-0738-9

Netemeyer, R. G., Bearden, W. O., \& Sharma, S. (2003). Scaling Procedures: Issues and Applications. Thousand Oaks, CA: Sage. doi: 10.4135/9781412985772

Newman, E., \& Reddy, L. A. (2017). Diagnostic utility of the Pediatric Attention Disorders Diagnostic Screener. Journal of Attention Disorders, 21(5), 372-380. doi: 10.1177/1087054714526431

Norvilitis, J. M., Ingersoll, T., Zhang, J., \& Jia, S. (2008). Self-reported symptoms of ADHD among college students in China and the United States. Journal of Attention Disorders, 11(5), 558-567. doi: 10.1177/1087054707308496

Overgaard, K. R., Aase, H., Torgersen, S., \& Zeiner, P. (2016). Co-occurrence of ADHD and anxiety in preschool children. Journal of Attention Disorders, 20(7), 573-580. doi: 10.1177/1087054712463063

Posserud, M. B., Ullebø, A. K., Plessen, K. J., Stormark, K. M., Gillberg, C., \& Lundervold, A. J. (2014). Influence of assessment instrument on ADHD diagnosis. European Child and Adolescent Psychiatry, 23(4), 197-205. doi: 10.1007/s00787-013-0442-6

Potter, A. S., Dunbar, G., Mazzulla, E., Hosford, D., \& Newhouse, P. A. (2014). AZD3480, a novel nicotinic receptor agonist, for the treatment of attention-deficit/hyperactivity disorder in adults. Biological Psychiatry, 75(3), 207-214. doi: 10.1016/j. biopsych.2013.06.002

Power, T. J., Costigan, T. E., Leff, S. S., Eiraldi, R. B., \& Landau, S. (2001). Assessing ADHD across settings: Contributions of behavioral assessment to categorical decision making. Journal of Clinical Child Psy- chology, 30(3), 399-412. doi: 10.1207/s15374424jccp3003_11

Raiker, J. S., Freeman, A. J., Perez-Algorta, G., Frazier, T. W., Findling, R. L., \& Youngstrom, E. A. (2017). Accuracy of Achenbach scales in the screening of attention-deficit/hyperactivity disorder in a community mental health clinic. Journal of the American Academy of Child \& Adolescent Psychiatry, 56(5), 401409. doi: 10.1016/j.jaac.2017.02.007

Re, A. M., \& Cornoldi, C. (2009). Two new rating scales for assessment of ADHD symptoms in Italian preschool children: A comparison between parent and teacher ratings. Journal of Attention Disorders, 12(6), 532539. doi: 10.1177/1087054708323001

Reyes-Sandoval, A. M., \& Acuña, L. (2012). Juicios de maestros sobre las conductas características del trastorno por déficit de atención e hiperactividad. Revista Latinoamericana de Psicología, 44(3), 65-82. Retrieved from https://editorial.konradlorenz.edu. co/rlp.html

Rowland, A. S., Umbach, D. M., Catoe, K. E., Stallone, L., Long, S., Rabiner, D., ... Sandler, D. P. (2001). Studying the epidemiology of attention-deficit hyperactivity disorder: Screening methods and pilot results. The Canadian Journal of Psychiatry, 46(10), 931-940. doi: 10.1177/070674370104601005

Sayal, K., Letch, N., \& El Abd, S. (2008). Evaluation of screening in children referred for an ADHD assessment. Child and Adolescent Mental Health, 13(1), 41-46. doi: 10.1111/j.1475-3588.2007.00463.x

Sikirica, V., Flood, E., Dietrich, C. N., Quintero, J., Harpin, V., Hodgkins, P., ... Haim-Erder, M. (2015). Unmet needs associated with attention deficit/hyperactivity disorder in eight European countries as reported by caregivers and adolescents: Results from qualitative research. The Patient-Centered Outcomes Research, 8(3), 269-281. doi: 10.1007/s40271-014-0083-y

Spencer, T. J., Biederman, J., \& Mick, E. (2007). Attention-deficit/hyperactivity disorder: Diagnosis, lifespan, comorbidities and neurobiology. Journal of Pediatric Psychology, 32(6), 631-642. doi: 10.1093/ 
jpepsy/jsm005

Sprafkin, J., Gadow, K. D., \& Nolan, E. E. (2001). The utility of a DSM-IV-Referenced screening instrument for attention-deficit/hyperactivity disorder. Journal of Emotional and Behavioral Disorders, 9(3), 182-191. doi: 10.1177/106342660100900304

Swanson, J. M., Kraemer, H. C., Hinshaw, S. P., Arnold, L. E., Conners, C. K., Abikoff, H. B., ... Wu, M. (2001). Clinical relevance of the primary findings of the MTA: Success rates based on severity of ADHD and ODD symptoms at the end of treatment. Journal of the American Academy of Child and Adolescent Psychiatry, 40(2), 168-179. doi: 10.1097/00004583200102000-00011

Tabachnick, B. G., \& Fidell, L. S. (2007). Using multivariate statistics $\left(5^{\text {th }}\right.$ ed.). Upper Saddle River, NJ: Pearson Allyn \& Bacon.

Vaquerizo-Madrid, J. (2005). Hiperactividad en el niño preescolar: Descripción clínica. Revista de Neurología, 40(1), 25-32. doi: 10.33588/rn.40S01.2005037

Wehmeier, P. M., Schacht, A., \& Barkley, R. A. (2010). Social and emotional impairment in children and adolescents with ADHD and the impact on quality of life. Journal of Adolescent Health, 46(3), 209-217. doi: 10.1016/j.jadohealth.2009.09.009

Willkut, E. G. (2012). The prevalence of DSM IV attention- deficit/hyperactivity disorder: A meta-analytic review. Neurotherapeutics, 9(3), 490-499. doi: 10.1007/s13311-012-0135-8

Wolraich, M. L., Lambert, E. W., Bickman, L., Simmons, T., Doffing, M. A., \& Worley, K. A. (2004). Assessing the impact of parent and teacher agreement on diagnosing attention-deficit hyperactivity disorder. Journal of Developmental and Behavioral Pediatrics, 25(1), 41-47. doi: 10.1097/00004703200402000-00007

World Health Organization. (2010). International Classification of Diseases, 10th revision. Geneva, Switzerland: World Health Organization.

World Health Organization. (2018). International Statistical Classification of Diseases and Related Health
Problems, ICD-11. Geneva, Switzerland: World Health Organization.

Ziegler, M. (2014). Stop and state your intentions! Let's not forget the $\mathrm{ABC}$ of test construction. European Journal of Psychological Assessment, 30(4), 239-242. 
Appendix 1.

ADHD-3P Scale for the screening of ADHD in early years of life (English version)

(Rodríguez-Becerra, Fernández-Mateos, \& Jenaro, 2019)

\section{Instructions}

Below there are a series of behaviors that your child may or may not manifest to different degrees. Please, respond to each question by indicating the degree to which your child manifests the following behaviors using the following criteria or levels of intensity:

NOTHING if is not manifest $=0$

LITTLE BIT if is not a relevant feature $=1$

QUITE if it is a frequent behavior $=2$

MUCH if is a typical feature for your child $=3$

Please try to answer all questions. Thank you very much for your cooperation.

\begin{tabular}{|c|c|c|c|c|c|c|}
\hline$\#$ & He or she: & $\mathbf{N}$ & $\mathbf{L}$ & $\mathbf{Q}$ & $\mathbf{M}$ & $\mathbf{F}$ \\
\hline 01. & Runs and jumps in inappropriate situations & 0 & 1 & 2 & 3 & $\mathrm{H}$ \\
\hline 02. & Is active & 0 & 1 & 2 & 3 & $\mathrm{H}$ \\
\hline 03. & Is impulsive and irritable (explosive episodes) & 0 & 1 & 2 & 3 & $\mathrm{O}$ \\
\hline 04. & Is restless, moving all the time & 0 & 1 & 2 & 3 & $\mathrm{H}$ \\
\hline 05. & It is prone to tantrums & 0 & 1 & 2 & 3 & $\mathrm{O}$ \\
\hline 06. & Talks excessively & 0 & 1 & 2 & 3 & $\mathrm{H}$ \\
\hline 07. & Fidgets with hands or feet or squirms in seat & 0 & 1 & 2 & 3 & $\mathrm{H}$ \\
\hline 08. & Is nervous & 0 & 1 & 2 & 3 & $\mathrm{H}$ \\
\hline 09. & Does not complete activities that he/she begins & 0 & 1 & 2 & 3 & I \\
\hline 10. & Does not grasp the meaning of "no" & 0 & 1 & 2 & 3 & $\mathrm{O}$ \\
\hline 11. & Is not invited to birthday parties or similar & 0 & 1 & 2 & 3 & $\mathrm{O}$ \\
\hline 12. & Does not seem to listen when spoken to & 0 & 1 & 2 & 3 & I \\
\hline 13. & Does not plan or develop a strategy for playing & 0 & 1 & 2 & 3 & I \\
\hline 14. & Does not pay attention to detail: is negligent & 0 & 1 & 2 & 3 & I \\
\hline 15. & $\begin{array}{l}\text { Does not pay attention for long periods of time } \\
(10 \text { minutes }) \text { or cannot concentrate }\end{array}$ & 0 & 1 & 2 & 3 & I \\
\hline 16. & Does not remember what he/she has done previously & 0 & 1 & 2 & 3 & I \\
\hline 17. & Is constantly running around & 0 & 1 & 2 & 3 & $\mathrm{H}$ \\
\hline 18. & Does not finish assignments & 0 & 1 & 2 & 3 & I \\
\hline 19. & Does not easily tolerate frustration & 0 & 1 & 2 & 3 & $\mathrm{O}$ \\
\hline 20. & Does not tolerate being still & 0 & 1 & 2 & 3 & $\mathrm{H}$ \\
\hline 21. & Has a difficult temperament & 0 & 1 & 2 & 3 & $\mathrm{O}$ \\
\hline 22. & Has difficulties playing quiet games & 0 & 1 & 2 & 3 & $\mathrm{H}$ \\
\hline 23. & Has difficulties organizing tasks & 0 & 1 & 2 & 3 & I \\
\hline 24. & Struggles to follow instructions and fails to finish tasks & 0 & 1 & 2 & 3 & I \\
\hline 25. & Shows difficulties waiting for his/her turn & 0 & 1 & 2 & 3 & $\mathrm{H}$ \\
\hline 26. & Has trouble with sitting down when required & 0 & 1 & 2 & 3 & $\mathrm{H}$ \\
\hline 27. & Touches everything although it is prohibited & 0 & 1 & 2 & 3 & $\mathrm{H}$ \\
\hline
\end{tabular}

Nota. $\mathrm{F}=$ Factor; $\mathrm{H}=$ Hyperactivity; $\mathrm{I}=$ Inattention; $\mathrm{O}=$ Other symptoms. 
Appendix 2.

ADHD-3P Escala para el cribado de TDAH en los primeros años de vida (versión en castellano) (Rodríguez-Becerra, Fernández-Mateos, \& Jenaro, 2019)

\section{Instrucciones}

A continuación se describen una serie de comportamientos que el niño/a puede o no manifestar en diferentes grados. Responda por favor a cada pregunta marcando con una cruz el grado en que el niño/a manifiesta las conductas indicadas a continuación, respondiendo a los siguientes criterios o niveles de intensidad:

NADA o no lo manifiesta $=0$

POCO o no es una característica relevante $=1$

BASTANTE o es una conducta frecuente $=2$

MUCHO o es una característica típica de su hijo/a $=3$

Por favor, trate de responder a todas las preguntas. Muchas gracias por su colaboración.

\begin{tabular}{|c|c|c|c|c|c|c|}
\hline N. ${ }^{\circ}$ & El niño o niña: & $\mathbf{N}$ & $\mathbf{P}$ & B & $\mathbf{M}$ & $\mathbf{F}$ \\
\hline 01 & Corre y salta en exceso en situaciones inapropiadas & 0 & 1 & 2 & 3 & $\mathrm{H}$ \\
\hline 02 & Es excesivamente activo/a & 0 & 1 & 2 & 3 & $\mathrm{H}$ \\
\hline 03 & Es impulsivo/a e irritable (episodios explosivos) & 0 & 1 & 2 & 3 & $\mathrm{O}$ \\
\hline 04 & Es inquieto/a, no para de moverse & 0 & 1 & 2 & 3 & $\mathrm{H}$ \\
\hline 05 & Es propenso/a a las rabietas & 0 & 1 & 2 & 3 & $\mathrm{O}$ \\
\hline 06 & Habla excesivamente & 0 & 1 & 2 & 3 & $\mathrm{H}$ \\
\hline 07 & Mueve en exceso las manos o los pies o se retuerce en su asiento & 0 & 1 & 2 & 3 & $\mathrm{H}$ \\
\hline 08 & Es nervioso/a & 0 & 1 & 2 & 3 & $\mathrm{H}$ \\
\hline 09 & No acaba las actividades que empieza & 0 & 1 & 2 & 3 & I \\
\hline 10 & No entiende el significado de "NO" & 0 & 1 & 2 & 3 & $\mathrm{O}$ \\
\hline 11 & No le invitan a las fiestas de cumpleaños o similar & 0 & 1 & 2 & 3 & $\mathrm{O}$ \\
\hline 12 & No parece escuchar cuando se le habla & 0 & 1 & 2 & 3 & I \\
\hline 13 & No planifica o elabora una estrategia para jugar & 0 & 1 & 2 & 3 & I \\
\hline 14 & No presta atención a los detalles: es descuidado/a & 0 & 1 & 2 & 3 & I \\
\hline 15 & $\begin{array}{l}\text { No presta atención durante mucho rato (10 minutos) o no puede concen- } \\
\text { trarse }\end{array}$ & 0 & 1 & 2 & 3 & I \\
\hline 16 & No recuerda lo que acaba de hacer & 0 & 1 & 2 & 3 & I \\
\hline 17 & Se mueve constantemente & 0 & 1 & 2 & 3 & $\mathrm{H}$ \\
\hline 18 & No termina lo que se le pide & 0 & 1 & 2 & 3 & I \\
\hline 19 & No tolera fácilmente la frustración & 0 & 1 & 2 & 3 & $\mathrm{O}$ \\
\hline 20 & No tolera la quietud & 0 & 1 & 2 & 3 & $\mathrm{H}$ \\
\hline 21 & Muestra un temperamento difícil & 0 & 1 & 2 & 3 & $\mathrm{O}$ \\
\hline 22 & Tiene dificultad para jugar a juegos tranquilos & 0 & 1 & 2 & 3 & $\mathrm{H}$ \\
\hline 23 & Tiene dificultad para organizar las tareas & 0 & 1 & 2 & 3 & I \\
\hline 24 & Tiene dificultad para seguir instrucciones y no logra terminar las tareas & 0 & 1 & 2 & 3 & I \\
\hline 25 & Tiene dificultades para esperar su turno & 0 & 1 & 2 & 3 & $\mathrm{H}$ \\
\hline 26 & Tiene problemas para sentarse cuando la situación lo requiere & 0 & 1 & 2 & 3 & $\mathrm{H}$ \\
\hline 27 & Toca todo lo que ve aunque esté prohibido & 0 & 1 & 2 & 3 & $\mathrm{H}$ \\
\hline
\end{tabular}

Nota. $\mathrm{F}=$ Factor; $\mathrm{H}=$ Hiperactividad; $\mathrm{I}=$ Inatención; $\mathrm{O}=$ Otros síntomas. 